\title{
PENGARUH DOSIS EKSTRAK JAMBU BIJI (PSIDIUM GUAJAVA. L) DAN TABLET Fe TERHADAP PERUBAHAN KADAR HEMOGLOBIN PADA MENCIT (MUS MUSCULUS)
}

\author{
Yusnaini \\ Staf Pengajar Jurusan Kebidanan Poltekkes Kemenkes Aceh
}

\begin{abstract}
According to the $\mathrm{WHO} 40 \%$ of maternal deaths in developing countries related to anemia in pregnancy and is most commonly caused by iron deficiency and acute bleeding, even less so the two interact. This study aims to determine the effect of doses of extracts of Guava (Psidium Guajava. L) and Tablet Fe to changes in hemoglobin levels in mice (Mus musculus). Type True Experimental studies in laboratory design nonrandomized design Pretest-Posttest Control Group Design. Samples were mice (Mus musculus) as many as 20 birds were divided into four groups with each group number as many as five tails. Group A was given a tablet Fe as much as $0.126 \mathrm{mg} / \mathrm{kg} /$ day, group B was given a tablet Fe as much as $0.126 \mathrm{mg} / \mathrm{KgBW} /$ day coupled with extracts of Guava as much as $10 \mathrm{mg} / \mathrm{kg} /$ day, group C was given tablets Fe as much as $0.126 \mathrm{mg} / \mathrm{kg} /$ day coupled with guava extract as much as $20 \mathrm{mg} / \mathrm{kg} /$ day, group D was given tablets as much as $0.126 \mathrm{mg} \mathrm{Fe} \mathrm{/} \mathrm{KgBW} /$ day plus guava extract as much as $30 \mathrm{mg} / \mathrm{kg} /$ day. The data collection was conducted from June $5 \mathrm{~s} / \mathrm{d}$ July 20, 2015. Data were analyzed using Paired T-Test continued with Test and One Way ANOVA Post Hoc Test namely LSD test. Results showed that there was no significant difference in hemoglobin levels between the groups in which the value of $P=0634>0.05$.. Based on the results of this study concluded that there was no effect of dose of extract of guava (Psidium Guajava. L) and Tablet Fe to changes in hemoglobin levels in mice (Mus musculus), but the effect on the number of erythrocytes of mice (Mus musculus).
\end{abstract}

Keywords : Extract of Guava, Tablet Fe, Mice, and Hemoglobin

\section{PENDAHULUAN}

Anemia merupakan suatu keadaan adanya penurunan kadar haemoglobin, hematokrit dan jumlah eritrosit dibawah nilai normal. Pada penderita anemia, lebih sering disebut kurang darah, kadar sel darah merah (haemoglobin atau $\mathrm{Hb}$ dibawah nilai normal). Penyebabnya bisa karena kurangnya zat gizi untuk pembentukan darah, misalnya zat besi, asam folat, dan vitamin B12.Tetapi yang sering terjadi adalah anemia karena kekurangan zat besi ${ }^{1}$.Anemia defisiensi besi adalah anemia yang disebabkan oleh kurangnya zat besi dalam tubuh. Faktor yang dapat menyebabkan timbulnya anemia defisiensi besi, antara lain karena kurangnya asupan zat besi dan protein dari makanan, adanya gangguan absorbsi diusus, perdarahan akut maupun kronis, dan meningkatnya kebutuhan zat besi seperti pada wanita hamil, masa pertumbuhan, dan masa penyembuhan dari penyakit ${ }^{1}$.

Anemia defisiensi besi pada wanita hamil merupakan problema kesehatan yang dialami oleh wanita diseluruh dunia terutama di Negara berkembang. Badan kesehatan dunia (World Health Organization/WHO) melaporkan bahwa prevalensi ibuibu hamil yang mengalami defisiensi besi sekitar 35-
75\% serta semakin meningkat seiring dengan pertambahan usia kehamilan. Di Indonesia berdasarkan Survey yang dilakukan sejumlah Fakultas Kedokteran dibeberapa Universitas di Indonesia pada tahun 2012 menemukan 50\%-63\% ibu hamil menderita anemia ${ }^{2}$.

Menurut WHO 40\% kematian ibu di Negara berkembang berkaitan dengan anemia pada kehamilan dan kebanyakan anemia pada kehamilan disebabkan oleh defisiensi besi dan perdarahan akut, bahkan tidak jarang keduanya saling berinteraksi. Pada wanita hamil sangat rentan terjadi anemia defisiensi besi, etiologi anemia defisiensi besi pada kehamilan yaitu : Hipervolemia yang menyebabkan terjadinya pengenceran darah, pertambahan darah tidak sebanding dengan pertambahan plasma, kurangnya zat besi dalam makanan dan kebutuhan zat besi meningkat serta gangguan pencernaan dan absorbsi ${ }^{1}$.

Kebutuhan wanita hamil akan besi meningkat sebesar 200-300\% yang digunakan untuk pembentukan plasenta dan sel darah merah. Perkiraan banyaknya besi yang diperlukan selama kehamilan sebanyak $1.040 \mathrm{mg}$. Sebanyak $300 \mathrm{mg}$ besi ditransfer ke janin, dengan rincian 50-75 mg untuk pembentukan plasenta, $450 \mathrm{mg}$ untuk penambahan sel darah merah, dan $200 \mathrm{mg}$ lenyap saat melahirkan. Jumlah sebanyak ini tidak mungkin 
tercukupi dari diet.Oleh karena itu suplemen zat besi sangat penting sekali, bahkan pada wanita yang status gizinya sudah baik.Penambahan besi terbukti dapat mencegah penurunan $\mathrm{Hb}$ akibat hemodilusi. Tanpa suplementasi cadangan besi dalam tubuh wanita akan habis pada akhir kehamilan'.

Suplementasi tablet zat besi adalah pemberian zat besi folat yang berbentuk tablet. Tiap tablet $60 \mathrm{mg}$ besi elemental dan 0,25 mg asam folat, yang diberikan oleh pemerintah pada ibu hamil untuk mengatasi masalah anemia gizi besi. Ibu hamil mendapatkan tablet tambah darah 90 tablet selama kehamilannya ${ }^{7}$. Pemberian zat besi dimulai setelah rasa mual dan muntah hilang yaitu memasuki usia kehamilan 16 minggu, dikonsumsi satu tablet sehari selama minimal 90 hari $^{8}$.

Tubuh sangat efisien dalam penggunaan besi, sebelum diabsorbsi di dalam lambung, besi dalam bentuk feri direduksi menjadi bentuk fero.Hal ini terjadi dalam suasana asam di dalam lambung dengan adanya $\mathrm{HCl}$ dan vitamin $\mathrm{C}$ yang terdapat dalam makanan ${ }^{1}$.

Absorbsi tablet besi atau $\mathrm{Fe}$ sangat ditunjang dengan adanya pemenuhan kebutuhan vitamin $\mathrm{C}$ dalam kapasitas normal. Kandungan vitamin $\mathrm{C}$ yang tinggi dapat diperoleh dalam buah jambu biji, dalam bahasa Latin jambu ini disebut Psidium Guajava, dalam Bahasa Inggris disebut Guava. Kita sering mengenalnya jambu klutuk.Buah ini sangat kaya vitamin $\mathrm{C}$ dan beberapa jenis mineral yang mampu menangkis berbagai jenis penyakit dan menjaga kebugaran tubuh. Daun dan kulit batangnya mengandung zat anti bakteri yang dapat menyembuhkan beberapa jenis penyakit .Selain vitamin $\mathrm{C}$, jambu biji juga mengandung potasium dan besi ${ }^{9}$.

Kandungan Vitamin $\mathrm{C}$ dalam jambu biji lebih tinggi daripada jeruk, dimana dalam 100 gram jambu biji mengandung $87 \mathrm{mg}$ vitamin $\mathrm{C}$. Kebutuhan vitamin $\mathrm{C}$ pada wanita golongan umur 10-12 tahun kebutuhan vitamin $\mathrm{C}$ sebanyak $50 \mathrm{mg}$ perhari, golongan umur 1315 tahun kebutuhan vitamin $\mathrm{C}$ sebanyak $65 \mathrm{mg}$ perhari dan golongan umur $>16$ tahun kebutuhan vitamin $\mathrm{C}$ sebanyak $75 \mathrm{mg}$ per hari, khusus pada ibu hamil kebutuhan vitamin $\mathrm{C}$ ditambah $10 \mathrm{mg}$ dari kebutuhan normal $^{10}$.

Tujuan Penelitian ini adalah untuk membuktikan pengaruh Dosis Ekstrak Jambu Biji (Psidium Guajava.L) dan Tablet Fe Terhadap Perubahan Kadar Hemoglobin dan Jumlah Eritrosit pada Mencit (Mus Musculus).

\section{METODOLOGI PENELITIAN}

Jenis penelitian ini bersifat True Experimental di Laboratorium, menggunakan Rancangan Nonrandomized Pretest-Postest Controled Group Design dengan 4 kelompok perlakuan.

Perlakuan yang diberikan seperti yang tertera pada tabel dibawah ini :

\begin{tabular}{llll}
\hline $\begin{array}{c}\text { Kelompok } \\
\text { A }\end{array}$ & $\begin{array}{c}\text { Kelompok } \\
\text { B }\end{array}$ & $\begin{array}{l}\text { Kelompok } \\
\text { C }\end{array}$ & $\begin{array}{c}\text { Kelompok } \\
\text { D }\end{array}$ \\
\hline $\mathrm{Fe} 0,126$ & Fe 0,126 & Fe 0,126 & Fe 0,126 \\
$\mathrm{mg} / \mathrm{kgBB})$ & $\mathrm{mg} / \mathrm{kgBB})$ & $\mathrm{mg} / \mathrm{kgBB})$ & $\mathrm{mg} / \mathrm{kgBB})$ \\
& + Ekstrak & + Ekstrak & + Ekstrak \\
& Jambu Biji & Jambu Biji & Jambu Biji \\
& 10 & 20 & 30 \\
& $\mathrm{mg} / \mathrm{kgBB}$ & $\mathrm{mg} / \mathrm{kgBB}$ & $\mathrm{mg} / \mathrm{kgBB}$ \\
\hline
\end{tabular}

Alat

Alat yang digunakan dalam penelitian ini adalah :

a. Kandang pemeliharaan dan perlengkapan milik FKH UNSYIAH.

b. Pemeriksaan kadar hemoglobin antara lain pipet dan hematology analyzer, kapas tisu, jarum.

c. Timbangan analitik kepekaan 0,001 gram.

d. Alat membuat ekstrak antara lain pisau, almari pengering, mortar.

e. Alat injeksi (syringe) kapasitas $3 \mathrm{ml}$ yang ujungnya diberi kanul digunakan untuk memberikan ekstrak ke mencit secara oral.

\section{Bahan}

Bahan yang digunakan dalam penelitian ini adalah mencit (Mus musculus) betina dewasa sebanyak 20 ekor yang berumur 8 minggu dengan berat 18-20 gram, berat badan dan umur mencit pada setiap kelompok sama, ekstrak Jambu Biji (Psidium Guajava) dan zat besi, pakan mencit berupa pellet AD2, EDTA, alkohol $70 \%, \mathrm{HCl} 0,1 \mathrm{~N}$ dan Aquades untuk pengencer ekstrak jambu biji. kelompok perlakuan adalah ibu hamil yang mengkonsumsi tablet Fe dan 100 gram juice jambu biji.

\section{Tahap persiapan}

Sebelum memberi perlakuan, mencit di aklimasi selama 1 minggu yang bertujuan agar mencit dapat beradaptasi dengan lingkungan yang baru sehingga diperoleh hewan percobaan yang benar-benar sehat dan normal, kemudian mencit di masukkan dalam kandang percobaan.

Mencit akan dipelihara dalam kandang yang terbuat dari bak plastik dengan penutup kawat. Alas kandang ditaburi serbuk gergaji yang bertujuan untuk mengurangi kedinginan dan mengurangi bau tidak sedap dari kotoran mencit, maupun pakan yang diberikan. Untuk 1 kelompok perlakuan menggunakan 5 mencit, mencit terlebih dahulu di anemiakan menggunakan $\mathrm{NaNO}_{2}$ yang diberikan sebanyak 125 $\mathrm{mg} / \mathrm{KgBB}$ kemudian dilakukan pemeriksaan hemoglobin dan jumlah eritrosit, lalu hewan coba dikawinkan dengan mencit jantan.

\section{Pembuatan Ekstrak Jambu Biji}

Pembuatan ekstrak tersebut dilakukan dengan cara jambu biji ditimbang lalu dihaluskan dengan menggunakan mortar. Kemudian dimasukkan ke dalam beaker gelas dan ditambahkan aquadest sebanyak $1 \mathrm{ml}$ sebagai pelarutnya. Diaduk-aduk dan didiamkan sebentar. Kemudian disaring hingga didapatkan ekstrak jambu yang dikehendaki (Ditjen POM, 1995). Ekstrak 
yang telah didapatkan diberikan kepada hewan uji Mus musculus secara oral dengan menggunakan jarum gavage. Volume pemberian ekstrak sebanyak 10,20 dan $30 \mathrm{mg} / \mathrm{KgBB} /$ hari (Hrapkiewicz \& Medina, 2007).

\section{Tahap perlakuan}

Selanjutnya, setelah mencit dalam kategori anemia dan hamil, maka diberikan perlakuan secara oral dengan dosis-dosis yang telah ditentukan. Pemberian perlakuan dilakukan setiap hari dan dalam sehari diberi ekstrak jambu biji dan tablet besi 1 kali per hari selama 20 hari. Ekstrak diberi secara oral pada mencit dengan mengunakan jarum gavage.

\section{Tahap pengambilan data}

Setelah tahap perlakuan pada hari ke-20 dilakukan kembali pengambilan sampel darah melalui vena mata. Kemudian dihitung kadar hemoglobin darah mencit tersebut.

\section{Tahap pengamatan}

a. Pembuatan sampel darah

Pengambilan sampel darah (Plexus Retroorbitalis) pada mata dengan cara Tikus dipegang dan dijepit bagian tengkuk dengan jari tangan, Tikus dikondisikan senyaman mungkin, kemudian Mikrohematokrit digoreskan pada medial canthus mata di bawah bola mata kearah foramen opticu, Mikrohematokrit diputar sampai melukai plexus, jika diputar 5x maka harus dikembalikan 5x. Darah ditampung pada Eppendorf yang telah diberi EDTA.

Darah segar untuk keperluan penelitian agar tidak menggumpal digunakan antikoagulasi: EDTA (Ethylene Diamin Tetra Acetic Acid).

Menurut Kosasih (1984), bahwa penentuan kadar hemoglobin salah satunya adalah dengan menggunakan metode Sahli dengan cara sebagai berikut. Tabung Hemometer diisi dengan 5 tetes $\mathrm{HCl}$ 0,1 N. Darah dihisap ke dalam pipet Sahli tepat hingga tanda garis 20 ul. Ujung pipet dibersihkan dan koreksi kelebihan darah dengan kapas atau kertas saring. Isi pipet dimasukkan ke dalam tabung hemometer yang telah dibubuhi $\mathrm{HCl}$. Pipet dibilas dengan beberapa kali menghisap dan meniup pipet dalam campuran tersebut. Pipet dikeluarkan dari tabung hemometer sambil meniupnya. Campuran tersebut dikeluarkan setelah 3-5 menit dengan air suling setetes demi setetes sambil diaduk dengan batang pengaduk gelas yang tersedia hingga warna dari campuran tersebut sama dengan warna standard. Pada perbandingan warna, tabung diletakkan demikian sehingga garis-garis pembacaan berada di samping serta dengan cahaya matahari sebagai latar belakang kemudian dilihat kadar hemoglobin.

Alat yang digunakan untuk mengukur kadar hemoglobin sebelum dan sesudah perlakuan adalah Hemoglobin Testing System Quik-Check. Pengolahan dan analisa data dengan program SPSS for windows versi $17.0 \mathrm{Uji}$ perbedaan kadar hemoglobin yang digunakan adalah uji t-test dependent dan t-test independent ${ }^{\mathbf{1 8}}$.

\section{HASIL DAN PEMBAHASAN}

Penelitian ini dilakukan terhadap 20 mencit hamil anemia yang dibagi menjadi 4 kelompok dengan masing-masing kelompok terdiri atas 5 mencit. Selanjutnya tiap kelompok diberikan perlakuan yaitu Kelompok A diberikan zat besi (dosis 0,126 $\mathrm{mg} / \mathrm{KgBB}$ ), Kelompok B diberikan zat besi (dosis $0,126 \mathrm{mg} / \mathrm{KgBB}$ ) ditambah ekstrak jambu biji (dosis 10 $\mathrm{mg} / \mathrm{KgBB}$ ), Kelompok $\mathrm{C}$ diberikan zat besi (dosis $0,126 \mathrm{mg} / \mathrm{KgBB}$ ) ditambah ekstrak jambu biji (dosis 20mg/KgBB), sedangkan Kelompok D diberikan zat besi (dosis 0,126 mg/KgBB) ditambah ekstrak jambu biji (dosis $30 \mathrm{mg} / \mathrm{KgBB}$ ).

a. Rerata Kadar Hemoglobin pada kelompok A

Tabel 1. Rerata Kadar Hemoglobin Mencit (Mus musculus) Pada Kelompok A (sebelum dan sesudah pemberian zat besi (Fe 0,126 mg/kgBB)

\begin{tabular}{lccc}
\hline \multirow{2}{*}{ Kelompok A } & \multicolumn{3}{c}{$\begin{array}{c}\text { Rerata Kadar } \\
\text { Hemoglobin }\end{array}$} \\
\cline { 2 - 4 } & Mean & SD & Sig. \\
\hline Sebelum & 11.880 & 1.8472 & 0.025 \\
Sesudah & 14.360 & 1.8783 & \\
\hline
\end{tabular}

Berdasarkan tabel 5.1 diatas dapat dilihat bahwa ada peningkatan kadar hemoglobin setelah dilakukan perlakuan dengan rata-rata peningkatan sebesar 2.48 gr/dl dan secara statistic terdapat perbedaan rata-rata kadar hemoglobin pada kelompok A sebelum dengan sesudah perlakuan.

b. Rerata Kadar Hemoglobin pada kelompok B

Tabel 2 Rerata Kadar Hemoglobin Mencit (Mus musculus) kelompok B sebelum dan sesudah pemberian zat besi (Fe $0,126 \mathrm{mg} / \mathrm{kgBB}$ ) dan Ekstrak Jambu Biji (10 mg/kgBB)

\begin{tabular}{lccc}
\hline \multirow{2}{*}{$\begin{array}{c}\text { Kelompok } \\
\text { B }\end{array}$} & \multicolumn{3}{c}{ Rerata Kadar Hemoglobin } \\
\cline { 2 - 4 } Mean & SD & Sig. \\
\hline Sebelum & 9.840 & 2.2199 & 0.526 \\
Sesudah & 10.840 & 2.1279 & \\
\hline
\end{tabular}

Berdasarkan tabel 5.2 diatas dapat dilihat bahwa ada peningkatan kadar hemoglobin setelah perlakuan dengan rata-rata peningkatan sebesar $1 \mathrm{gr} / \mathrm{dl}$, namun secara statistic terlihat tidak ada perbedaan signifikan rata-rata kadar hemoglobin pada kelompok B sebelum dengan sesudah perlakuan. 
c. Rerata Kadar Hemoglobin pada kelompok C

Tabel 3 Rerata Kadar Hemoglobin Mencit (Mus musculus) kelompok C sebelum dan sesudah pemberian zat besi ( $\mathrm{Fe}$ 0,126 mg/kgBB) dan Ekstrak Jambu Biji (20 mg/kgBB)

\begin{tabular}{lccc}
\hline Kelompok & \multicolumn{3}{c}{ Rerata Kadar Hemoglobin } \\
\cline { 2 - 4 } \multicolumn{1}{c}{ C } & Mean & SD & Sig. \\
\hline Sebelum & 9.800 & 2.0736 & 0.078 \\
Sesudah & 12.920 & 1.0825 & \\
\hline
\end{tabular}

Berdasarkan tabel 5.3 diatas dapat dilihat bahwa ada peningkatan kadar hemoglobin setelah dilakukan perlakuan dengan rata-rata peningkatan sebesar 3.12 gr/dl, namun secara statistik terlihat tidak ada perbedaan yang signifikan rata-rata kadar hemoglobin pada kelompok $\mathrm{C}$ sebelum dengan sesudah perlakuan.

d. Rerata Kadar hemoglobin pada kelompok D

Tabel 4 Rerata Kadar Hemoglobin Mencit (Mus musculus) kelompok D sebelum dan sesudah pemberian zat besi (Fe 0,126 mg/kgBB) dan Ekstrak Jambu Biji (30 mg/kgBB)

\begin{tabular}{lccc}
\hline \multirow{2}{*}{ Kelompok D } & \multicolumn{3}{c}{ Rerata Kadar Hemoglobin } \\
\cline { 2 - 4 } & Mean & SD & Sig. \\
\hline Sebelum & 11.400 & 0.8124 & 0.144 \\
Sesudah & 13.360 & 2.2601 & \\
\hline
\end{tabular}

Berdasarkan tabel 5.4 diatas dapat dilihat bahwa ada peningkatan kadar hemoglobin setelah dilakukan perlakuan dengan rata-rata peningkatan sebesar 1.96 gr/dl, namun secara statistik terlihat tidak ada perbedaan yang signifikan rata-rata kadar hemoglobin pada kelompok D sebelum dengan sesudah perlakuan.

\section{Perbedaan Kadar Hemoglobin}

Berdasarkan hasil Uji Statistik ANOVA untuk melihat perbedaan rata-rata kadar hemoglobin pada semua kelompok, diperoleh nilai $\mathrm{P}=0.634$ ( $\mathrm{p}>0.05)$ dapat disimpulkan bahwa tidak ada perbedaan rata-rata kadar hemoglobin antar kelompok A, B, C dan D. Namun, setelah diberi perlakuan pada masing-masing kelompok terlihat adanya peningkatan kadar hemoglobin, sebagaimana terlihat ditabel berikut ini :

Tabel 5. Hasil Uji (Anova) Perbedaan Kadar Hemoglobin Mencit (Mus musculus) antar kelompok A, B, C dan D

\begin{tabular}{cllll}
\hline \multirow{2}{*}{ Kelompok } & $\begin{array}{c}\text { Dosis zat besi } \\
\text { dan ekstrak } \\
\text { jambu biji }\end{array}$ & \multicolumn{3}{c}{ Rerata kadar hemoglobin } \\
\cline { 3 - 5 } $\mathrm{A}$ & Mean & SD & Sig. \\
\hline \multirow{2}{*}{$\mathrm{Fe} 0,126$} & 2.480 & 1.5849 & \\
$\mathrm{mg} / \mathrm{kgBB}$. & & & \\
& $\begin{array}{l}\text { Fe } 0,126 \\
\mathrm{mg} / \mathrm{kgBB}) \text { dan }\end{array}$ & 1.000 & 3.2249 & \\
& $\begin{array}{l}\text { Ekstrak Jambu } \\
\text { Biji } 10 \mathrm{mg} / \mathrm{kgBB}\end{array}$ & & & 0.634 \\
& & &
\end{tabular}

\begin{tabular}{|c|c|c|c|}
\hline $\mathrm{C}$ & $\begin{array}{l}\text { Fe } 0,126 \\
\mathrm{mg} / \mathrm{kgBB} \text { ) dan } \\
\text { Ekstrak Jambu } \\
\text { Biji } 20 \mathrm{mg} / \mathrm{kgBB}\end{array}$ & 3.120 & 2.9584 \\
\hline D & $\begin{array}{l}\text { Fe } 0,126 \\
\mathrm{mg} / \mathrm{kgBB} \text { ) dan } \\
\text { Ekstrak Jambu } \\
\text { Biji } 30 \mathrm{mg} / \mathrm{kgBB}\end{array}$ & 1.960 & 2.4183 \\
\hline
\end{tabular}

Menurut manuaba (2001), Respon terhadap pengobatan dengan tablet $\mathrm{Fe}$ pada ibu hamil terpantau melalui perbaikan nilai hemoglobin yang meningkat paling sedikit $0,3 \mathrm{gr} / \mathrm{dl} / \mathrm{minggu}$. Menurut Patimah (2007) bahwa zat besi merupakan prekursor yang sangat diperlukan dalam pembentukan hemoglobin dan sel darah merah (eritrosit).

Hal ini terlihat dari adanya peningkatan kadar hemoglobin pada tiap kelompok setelah diberikan perlakuan. Hasil penelitian tersebut juga sesuai dengan temuan Mulyawati tahun 2004, pada pekerja wanita di Perusahaan Plywood, Jakarta yang menunjukkan bahwa terjadi peningkatan rata-rata kadar hemoglobin sebesar $2.19 \mathrm{gr} / \mathrm{dl}$ setelah intervensi dengan mengkonsumsi tablet $\mathrm{Fe}$ selama jangka waktu 16 minggu.

\section{KESIMPULAN}

Berdasarkan hasil penelitian yang telah dilakukan dapat bahwa : Ada peningkatan rata-rata kadar hemoglobin (2.48 gr/dl dengan nilai $\mathrm{p}=0.025)$ pada kelompok A, Ada peningkatan rata-rata kadar hemoglobin (1 gr/dl dengan nilai $\mathrm{p}=0.526$ ) pada kelompok B, Ada peningkatan rata-rata kadar hemoglobin (3.12 gr/dl dengan nilai $\mathrm{p}=0.078)$ pada kelompok $\mathrm{C}$, Ada peningkatan rata-rata kadar hemoglobin (1.96 gr/dl dengan nilai $\mathrm{p}=0.144)$ pada kelompok D dan Tidak terdapat perbedaan yang nyata kadar hemoglobin antar perlakuan $(\mathrm{p}=0.634>0.05)$.

Kepada peneliti lanjutan, untuk dapat mengembangkan penelitian lebih lanjut tentang pengaruh ekstrak jambu biji terhadap hemoglobin dan eritrosit pada ibu hamil terutama memperhatikan proses pembuatan ekstrak jambu biji agar kandungan Vitamin $\mathrm{C}$ dalam jambu biji tidak berubah.

\section{DAFTAR PUSTAKA}

1. Amiruddin, dkk (2007). Evidence based Epidemiologi Anemia Deficiensi zat besi pada ibu hamil di Indonesia. http://ridwanamiruddin.com/2007/10/08/evidencebase-epidemiologi-anemia-deficiensi-zat-besipada-ibu-hamil-di-indonesia/ diakses 15 Oktober 2013.

2. Media Indonesia (2013). Tinggi, Prevalensi Anemia di Indonesia. Kliping Berita Kesehatan. Pusat Komunikasi Publik Setjen Kementerian Kesehatan RI. Rabu, 3 April 2013 halaman 24.

3. Kementerian Kesehatan RI Direktorat Jenderal Bina Gizi dan KIA (2012). 
4. Dinas Kesehatan Pemerintah Provinsi Aceh. Profil Kesehatan Provinsi Aceh (2007).

5. Dinas Kesehatan Pemerintah Provinsi Aceh. Profil Kesehatan Propinsi Aceh (2011).

6. Arisman, MB. (2004). Gizi dalam Daur Kehidupan: Buku Ajar Ilmu Gizi. Jakarta : EGC.

7. Depkes RI (2010). Laporan Nasional Riset Kesehatan Dasar (Riskesdas). Jakarta.

8. Salmah, dkk (2006). Asuhan Kebidanan Antenatal. Jakarta : Buku Kedokteran EGC.

9. Dekha Care (2013). Kandungan Vitamin C dan Manfaat Jambu Biji. http://www.dechacare.com/Kandungan-VitaminC-dan-Manfaat-Jambu-Biji-I471.html. Di akses pada tanggal 16 Oktober 2013.

10. Herlanti, Y (2010). Angka Kecukupan Gizi. Nutrition Educational. http://yherlanti.files.wordpress.com/2011/08/06pertemuan-9-revisi.pdf. Di akses pada tanggal 16 Oktober 2013.

11. Evelyn C, P (2009). Anatomi dan Fisiologi untuk Paramedis.Jakarta : PT. Gramedia Pustaka Utama.

12. Brooker, R. et al (2011). Biology. Mc Graw-Hill.

13. Depkes RI (2007). Pedoman Penanggulangan Anemia Gizi di Indonesia. Jakarta: Direktorat Bina Gizi Masyarakat.

14. Shinta, Annisa. (2005). Hubungan Antara Kadar Hemoglobin Dengan Prestasi Belajar Siswi SMP Negeri 25 Semarang. Skripsi Fakultas Kesehatan Masyarakat Universitas Negeri Semarang. http://digilib.unnes.ac.id/gsdl/collect/skripsi/archi ves/HASH5363/e10abea1.dir/doc.pdf. Diakses pada tanggal 20 Oktober 2013.

15. Arisman (2002). Gizi dalam Daur Kehidupan. Bagian Ilmu Gizi Fakultas Kedokteran Universitas Palembang. Proyek Peningkatan Penelitian Pendidikan Tinggi. Direktorat Jenderal Pendidikan Tinggi. Depdiknas.

16. Wikipedia (2007). Hemoglobin. http://id.wikipedia.org/wiki/Hemoglobin. Diakses pada tanggal 22 Oktober 2013.

17. Almatsier, S (2001). Prinsip Dasar Ilmu Gizi. Jakarta : Gramedia Pustaka Utama.

18. Zarianis (2006). Efek Suplementasi Besi-Vitamin $C$ dan Vitamin $C$ terhadap Kadar Hemoglobin Anak Sekolah Dasar yang Anemia di Kecamatan Sayung Kabupaten Demak. Tesis. Program Magister Gizi Masyarakat Universitas Diponegoro Semarang. http://eprints.undip.ac.id/15967/1/Zarianis.pdf. Diakses pada tanggal 16 Oktober 2013.

19. Almatsier, S (2002). Prinsip Dasar Ilmu Gizi. Gramedia Pustaka Utama. Jakarta.

20. Bachyar, dkk. (2002). Penilaian Status Gizi. Buku Kedokteran EGC : Jakarta.

21. Waryana (2010). Gizi Reproduksi. Pustaka Rihama : Yogyakarta.
22. Wikjosastro, H (2005). Ilmu Kebidanan. Ed 3. Yayasan Bina Pustaka Sarwono Prawirohardjo: Jakarta.

23. Varney, H. (2007). Buku Ajar Asuhan Kebidanan. Edisi 4, Volume 2. Jakarta: EGC.

24. Depkes, RI. (2000). Pedoman Pemberian Besi bagi petugas. Ditjen Kesehatan Masyarakat. Jakarta.

25. Supariasa, dkk (2001). Penilaian Status Gizi. Jakarta: EGC.

26. Manuaba (2002). Ilmu Kebidanan, Penyakit Kandungan dan KB untuk Pendidikan Bidan.Jakarta : EGC.

27. Arief, N (2008). Panduan Lengkap Kehamilan dan Kelahiran Sehat. Jogyakarta : AR Group.

28. Manuaba (2007). Pengantar Kuliah Obstetri. Penerbit Buku Kedokteran EGC: Jakarta.

29. Pusdiknakes (2003). Asuhan Antenatal.Jakarta : Pusdiknakes.

30. Varney, H. (2002). Buku Saku Bidan. Penerbit Buku Kedokteran EGC : Jakarta.

31. Soebroto, I. (2009). Cara mudah mengatasi problem Anemia. Yogyakarta: Bangkit.

32. Maulana, H (2009). Promosi Kesehatan. Jakarta : EGC.

33. Arisman, MB. (2010). Gizi Dalam Daur Kehidupan. Buku Ajar Ilmu Gizi.EGC : Jakarta.

34. Musbikin (2008). Panduan Kontrasepsi.Jogyakarta : Mitra Pustaka.

35. Wikipedia (2013). Jambu Biji. http://id.wikipedia.org/wiki/Jambu_biji. Di Akses pada tanggal 16 Oktober 2013.

36. Depkes RI (2005). Piranti Lunak NutriClin. versi 2.0 edisi kedua, Subdit Gizi Klinis, Departemen Kesehatan Indonesia, Jakarta.

37. L. Wong, dkk (2009). Buku Ajar Keperawatan Pediatrik. Volume 1. EGC : Jakarta.

38. Smith, J.B dan Mangkuwidjoyo, S (1998). Pemeliharaan, Pembiakan dan Penggunaan hewan percobaan di daerah tropis. Cetakan pertama. UI Press. Jakarta.

39. Arrington, L.R dan K.C Kelley (1972). Domestic Rabbit Biology and Production The University Press Of Floride Gainesville.

40. Manuaba (2001). Kapita Selekta Penatalaksanaan Rutin Obstetri Ginekologi dan KB. Penerbit Buku Kedokteran EGC. Jakarta.

41. Patimah, S (2007). Pola Konsumsi Ibu Hamil dan Hubungannya Dengan Kejadian Anemia Defisensi Besi. Jurnal Penelitian Kesehatan. Jakarta: Fakultas Kedokteran.

42. Mulyawati, Y (2003). Perbandingan efek suplementasi tablet tambah darah dengan dan tanpa vitamin $C$ terhadap kadar hemoglobin pada pekerja wanita di Perusahaan Plywood, Jakarta. Program Pasca Sarjana Universitas Indonesia.

43. Syaifuddin (2009). Fisiologi Tubuh Manusia. Edisi Kedua. Salemba Medika. Jakarta. hlm. 2528. 
44. Almatsier, S (2001). Prinsip Dasar Ilmu Gizi. PT. Gramedia Pustaka Utama. Jakarta. hlm. 185-253, 256.

45. Andanna, D dan Sri, S (2006). Hubungan Konsumsi Protein Hewani dan Zat Besi dengan Kadar Hemoglobin Pada Balita Usia 13-36 Bulan. The Indonesian Journal Of Public Health 3(1): 22.
46. Hoffbrand, A. V, J. E. Pettit., P. A. H. Moss (2005). Kapita Selekta Haemotologi. Edisi 4. Jakarta: EGC Penerbit Buku Kedokteran. hlm 1-3.

47. Ganong, D.C. (1983). Fisiologi Kedokteran. Edisi 10. Jakarta: EGC Penerbit Buku Kedokteran. hlm. 449-456. 